\title{
Trajectories in the Development of Islamic Theological Thought: the Synthesis of Kalām
}

\author{
Mustafa Shah*
}

School of Oriental and African Studies, London University

\begin{abstract}
The field of Islamic theology (kalām) is not merely a receptacle for the presentation of the creedal statements and doctrinal catechisms of Islam; it derives its raison d'être not only from the articulation and elucidation of the doctrines of faith, but also by means of its rational and painstaking explication of dogma. While many of the dogmatic statements expressed in Islamic theology naturally emanate from a traditional substratum, countless more are the result of dialectical discussions as theologians expounded upon abstract constructs of religious dogma. Recent academic research is exploring the history, trends and conceptual achievements behind the Islamic experiment with theology, providing insights into the tradition's ability to integrate, refine and expand theological constructs. Scholars are also concerned with issues such as origins, authenticity and ascription, although such matters are not deflecting attention from the rich stock of resources and materials kaläm has to offer.
\end{abstract}

\section{Defining Kalām}

Despite the somewhat pervasive background of the term kalam in the classical Islamic tradition, it is in the realm of religious dogma that the term, which literally denotes speech, acquired formal significance, serving as a generic name for the Muslim discipline of theology. The theology associated with kalām was not simply a catechism of religious creeds as sourced to scriptural dicta, but it also embodied the rational explication of theological doctrines. It was under the aegis of the kalàm umbrella that a rich and diverse stock of literature was developed. This included treatises that expounded upon creeds; polemical tracts and epistles; historical surveys of religious movements and sects within the Islamic tradition; and even apologetic treatises dealing with Judaism, Christianity and Zoroastrianism. In the same way that jurisprudence ( fiqh), Qur'anic exegesis (tafsìr), prophetic traditions (hadìth), history (sìra), grammar and the study of language ('arabiyya) emerged as autonomous disciplines within the classical Islamic tradition, ilm al-kaläm (the science of dialectics) carved out its own smaller niche among the Islamic traditional sciences. Kalām had acquired two inter-related senses: first, in its wider generic sense kalàm provided a platform for the rational synthesis of the 
panoply of religious dogmas and was viewed as being a form of scholastic theology, which was also defined under the rubric ușull al-dinn (the roots of faith); while, in a more confined sense, it was used to connote a sophisticated dialectical technique based on a form of dialogue that was employed by scholars engaged in theological discussions. Despite the early historical roots of this technique within the Islamic tradition, the broader meaning of the term prevailed with kalām becoming synonymous with the discipline of theology. Recent academic research is exploring the history, trends and theoretical achievements behind the Islamic experiment with theology, providing insights into the tradition's ability to integrate, refine and expand theological constructs. Issues such as origins, influences, tensions between traditionalist and rationalist approach to the formulation of dogma, and the consolidation of religious orthodoxy within the Islamic tradition have featured prominently in academic treatments of the subject. Furthermore, the contribution to the synthesis of theological thought made by sects and religious movements outside the traditional confines of orthodoxy is increasingly attracting the attention of researchers, confirming the rich stock of resources and materials the discipline of kaläm has to offer.

\section{The Early Sources: Authenticity and Ascription}

Attempts to examine the historical development of the religious institutions and features of the early Islamic tradition are ultimately beset by methodological arguments regarding the authenticity of the earliest available materials. The problem is not restricted to the field of theology but extends across the gamut of the early Islamic sciences. Modern scholarship tends to take the view that while the classical sources reveal much that is pertinent to an understanding of the history of Islam, the tradition's portrayal of its past is not necessarily furnishing historical fact but rather projecting an idealistic impression of its own emergence. Two broad approaches to the sources have been recently summarised by Herbert Berg: notwithstanding a continuum in the compass of approaches, the first of these tends to argue that it is possible using a distinct measure of critical analysis to discern conclusive historical facts in the corpus of early material and use these to present a fairly accurate depiction of the early Islamic tradition. ${ }^{1}$ Conversely, a second camp takes the view that the vast corpus of material purported to represent the scholarship and religious ideals of the first two centuries of the Islamic tradition is the insidious product of salvation history and projection; the sources were a subjective quest for the religious import of Islam by early Muslim scholars inspired yet separated from the emergence of this faith by decades of history. ${ }^{2}$ This view postulates that the finely developed practices and doctrines that are attributed to the founding fathers of the Islamic tradition are essentially the conscious creation of later generations of faithful adherents.

It is not difficult to appreciate the extent to which such methodological differences and approaches impinge upon attempts to unravel the history 
and development of kalām. A large number of the texts and treatises that are attributed to luminaries from the early Islamic tradition are usually recovered and quoted in sources from subsequent chronological periods. Many of the earliest texts are assumed to be pseudepigraphic in origin. Indeed, in general as far as the first two centuries of the tradition are concerned, there seldom exists full and original manuscript evidence from the actual period in which the writer of a text is believed to have lived. ${ }^{3}$ This does not necessarily prove that purportedly early texts were the products of fabrication, but it underlines some of the problems faced when dating these materials and the originality of the ideas they comprise. The modes of oral and written transmission perfected by classical Muslim scholarship are rather sophisticated; and scholars from within the tradition were clearly aware of accepted conventions and the variety of safeguards applied in the transmission of texts. ${ }^{4}$ Nevertheless, the fact that projection and ascription might be used to furnish theological ideas with historical depth and aspect explains why 'sceptical' academic scholarship adopts a rather negative attitude towards attempts to reconstruct the early history of theology and many of the other traditions of Islam.

\section{Early Theological Constructs}

Among the developed theological themes particular salient in early Islamic thought are the topics of postponement (irja $\vec{a}$ ) and predestination (qadar). Classical Arabic sources intimate that the theoretical discourse that developed around these issues ultimately has its origin in the political disputes concerning the issue of leadership of the community. The concept of irja was developed as a result of polemical discussions on the subject of the status of sinners in Islam. Following the civil war of Siffin (35/657 CE) between the fourth caliph 'Alī ibn Abī Ṭālib (d. 40/661 CE) and his rival Mu'āwiya ibn Abī Sufyān (d. 60/680 CE), disagreements arose regarding 'Alī's decision to accept arbitration. It was viewed by some as being an act of apostasy, rendering him a grave sinner. ${ }^{5}$ The formulation of the concept of $i r j \vec{a}$ was one way of attenuating the theological sensitivities of the debate for it stressed that judgement on such issues should be deferred to God. Advocates of this concept were referred to as Murji ites; while those who equated grave sins with disbelief and apostasy earned notoriety as the Khārijites, a radical movement that developed doctrines commensurate with its puritanical outlook. A political nexus is also identified in the theoretical debates surrounding the doctrine of predestination. At stake was the religious legitimacy of Umayyad rule, which was established by Mu'āwiya in 41/661 $\mathrm{CE}$ in the aftermath of the events at Siffin. However, issues such as free will, responsibility and the theodicy were later woven into the texture of arguments on the subject. ${ }^{6}$ Individuals who defended the ideas of free will and responsibility were referred to as Qadarites or ahl al-qadar; many of them were political opponents of the Umayyads. ${ }^{7}$ Modern scholarship tends to 
see the Qadarites as being precursors to the rational theological movement of the second/seventh century $\mathrm{CE}$, whose adherents were known as Mu'tazilites. They placed reason at the heart of their interpretation of religious dogma, and played a significant role in the development of speculative kalām.

An eminent academic authority on Islamic theology, Joseph van Ess, produced a number of critical editions of theological texts, which, despite being ascribed to luminaries of the early Islamic tradition, were actually collated from sources of a much later provenance. These included treatises on the doctrines of postponement $\left(i r j \vec{a}^{>}\right)$and predestination (qadar). Van Ess was seeking to explore the historical development of kaläm together with the ideas and movements that contributed to this discipline. He also wanted to probe the origin of the dialectical technique employed by Muslim theologians. According to van Ess, the technique centred on a presupposed dialogue with an opponent in which a defined question is presented in order to flesh out a particular doctrine or idea. The attendant response to this hypothetical question would then prompt a further series of questions and answers until an opponent is forced to admit a consequence which contradicts his own thesis', ultimately reducing him to silence; later kalām literature is replete with examples of this discourse. ${ }^{8}$ Van Ess was convinced that Christian influences had exercised a key role in the inception of kalām and that converts from Christianity had served as conduits for the transmission of dialectical methods. Previous research by Carl Heinrich Becker had claimed that intense religious disputation among Christians and Muslims had provided a pivotal locus for the infusion of the kalàm technique, with the latter having to master this vital polemical instrument. Becker additionally argued that Christian polemics had an impact upon Islamic theological thought. ${ }^{9}$

One of the early tracts examined by van Ess was ascribed to al-Hasan ibn Muhammad ibn al-Hanafiyya (d. 100/718 CE). It was preserved in the writings of al-Hādī ila’l-Haqq Yạ̣yā ibn al-Ḥusayn (d. 298/911 CE), a prominent Zaydite luminary. The Zaydites are traditionally viewed as representing a moderate $S h^{-c}$ ite movement. The Shî ${ }^{-c}$ ites were supporters of the third caliph 'Alī. They contended that leadership of the community was a divinely conferred right that belonged to 'Ali and a specified number of his direct descendants; it became an important tenet of Shi' ism. Among these Shî ite groups those who recognised the authority and succession of twelve leaders (imāms) were called twelvers; while those who acknowledged seven designated imāms were subsequently identified as the Ismāi $1 \bar{l}$ s. ${ }^{10}{ }^{1}$ The text ascribed to al-Hasan dealt with questions against the Qadarites. ${ }^{11}$ Based on his review of these texts, van Ess drew a number of broad conclusions about the development of Islamic theology. Among these was the view that nascent theological ideas were often predisposed to later perceptions of orthodoxy and that a familiarity with the dialectical technique of kaläm was evident in these early tracts. ${ }^{12}$ Van Ess was convinced that there did exist 
written literature in the first century of Islam. Most significantly, van Ess dismissed the idea that the first systematic and rational theologians of Islam, the Mu'tazilites, had actually pioneered this dialectical technique. He was likewise surprised to find that the Hijāzī milieu, the geographical homeland of the Islamic tradition, which was traditionally seen as a bastion of orthodoxy and traditionalism, had provided the setting in which the innovative methods of dialectical discourse were developed. Previously, cosmopolitan centres in Iraq and Syria were seen as strategic loci for the diffusion of Judeo-Christian thought into the Islamic tradition. Van Ess remarked that the concept of irja $\bar{a}^{3}$, as explored in al-Hasan ibn Muhammad ibn al-Hanafiyya's text, was aimed at reining in radical Shì ite movements. ${ }^{13} \mathrm{He}$ added that it also gave birth to the quietist religious movement of the Murji ites. ${ }^{14}$

Van Ess's analysis of these early kalām sources was the subject of two separate studies by Michael Cook. In a brief but incisive article, Cook disputed van Ess's dating of the so-called tract against the qadariyya, suggesting that the kaläm technique, which was primitively employed in al-Hasan's text, may well have been based on Syriac prototypes. ${ }^{15}$ Cook was making the point that attempts to resolve the issue of the origins and development of kalām required a much more extensive corpus of primary sources than hitherto available. Cook returned to the issue of dating these theological works in a separate in-depth critical monograph. ${ }^{16}$ The treatises and tracts upon which van Ess had relied were believed by Cook to be pseudepigraphic in origin. He argued that these texts should have been sourced to the late Umayyad period (ca. 133/750 CE). Van Ess's dating of the texts implied that there existed an acute perception of critical theological issues at early stages within the Islamic tradition; accordingly, an awareness of notions germane to those discussed in these tracts must have naturally predated the texts in question, implying a greater historical depth to the whole Islamic theological tradition. ${ }^{17}$ However, if one were to subscribe to the view that these tracts were the products of deliberate projection then the historical value of such texts is somewhat compromised.

The impact of arguments regarding ascription and the so-called pseudepigraphic origin of materials is evident in discussions regarding the authenticity of a theological epistle ascribed to the mystic and luminary al-Hasan al-Bașri (d. 110/728 CE). He is said have to have composed this epistle, entitled al-Risāla fi'l-qadar, in response to a question from the Umayyad caliph 'Abd al-Malik ibn Marwān (d. 86/705 CE). ${ }^{18}$ Al-Hasan offered an intrepid refutation of predestination, using verses from the Qur'an to place distance between God and the existence of evil. He concluded that man is a free agent responsible for his deeds, a theological position adopted among Qadarites and later Mu'tazilites. Consequently, it led to the supposition that such deeds were not subject to God's sovereign will. Orthodoxy felt that from a conceptual perspective this interpretation of free will undermined the reality of God's omnipotence. ${ }^{19}$ Verses of the Qur'an could be adduced 
to support both deterministic and libertarian positions. By implication, the thoughts expressed in this epistle suggest that its author, al-Hasan al-Bașrī, was actually a Qadarite, a view contested by Sunnī theologians. The Sunnites or ahl-al-Sunna represent the principal religious denomination within the Islamic tradition and are divided along theological lines into several camps: the staunch traditionists (ahl-al-hadith); the Ash'arites and the Māturīdites. ${ }^{20}$ The doctrine of predestination was endorsed as one of the standards of Sunnī orthodoxy. A number of key figures mentioned in the sources as having espoused libertarian doctrines are linked with al-Hasan: these include Ma'bad al-Juhan̄̄ (d. 80/699 CE) and Ghaylān al-Dimashqī (d. 125/743 CE), both of whom were executed for insurrection by the Umayyads. Classical Arabic biographical literature does mention that al-Hasan had been a Qadarite, although he is said to have relinquished this conviction. The author of the doxography of religious sects and movements al-Shahrastānī (d. 548/1153 CE) maintained that given the epistle's contents, it was inconceivable that al-Hasan could have been its author. Mu'tazilite literature accentuated al-Hasan's links with this epistle as they claimed him as one of their founding fathers.

The Risâla fìl-qadar, like Ibn al-Hanafiyya's tracts was quoted from a later source, namely, a biographical dictionary extolling the virtues of the Mu'tazilites (Fậl al-I'tizāl wa Tabaqāt al-Mu'tazila) by the fourth/tenth century Mu'tazilite theologian 'Abd al-Jabbār (d. 415/1024 CE). It was also cited in a number of versions in the Hilyat al-awliy $\vec{a}$, a biographical dictionary of Sufi luminaries composed by Abū Núaym al-Iṣfahān̄i (d. 430/1038 $\mathrm{CE}$ ). Van Ess accepted the authenticity of this text, circumscribing it to the following periods 75-80/694-699 CE, although he later conceded that a slightly later date for the text was possible. He reasoned that the noticeable absence of references to prophetic traditions (hadith), which were frequently adduced in later literature to endorse the doctrine of predestination, confirmed the early provenance of this epistle. The reasoning is that these traditions were fabricated much later by orthodox scholars keen to defend the doctrine of predestination. It is claimed that at the time of al-Hasan such traditions were not yet in circulation; otherwise, the epistle would have taken the opportunity to refute them. ${ }^{21}$ Scholars such as Helmut Ritter, Julian Obermann and Michael Schwarz all accepted the text's authenticity and spoke of the originality of its ideas. ${ }^{22}$ John Wansbrough concluded that the text emanated from the late second (eighth) century. He reasoned that the conspicuous absence of prophetic traditions was due to the text being prefigured to address the debate within Islam about the authority of sources: ușull. The epistle was essentially about accentuating the independent authority of the Qur'an to the exclusion of the prophetic traditions; in Wansbrough's estimation, by design, the epistle would not have comprised prophetic traditions and therefore their absence should not be used to buttress arguments for the text's early origins. 
An examination of the epistle was included in Cook's monograph. ${ }^{23}$ In his opinion the text was pseudepigraphic in origin: it belonged to the late Umayyad period. More recently the epistle's authenticity has been the subject of an extended study by Suleiman Mourad. This study raises once more the historical value of the early Islamic sources and the materials they comprise. ${ }^{24}$ Mourad claimed that the style, language and composition of the epistle betrayed its late provenance. He believed that the text reflected theological debates of the third/ninth and fourth/tenth centuries CE, floating the idea that the aforementioned $\mathrm{Mu}^{\mathrm{C}}$ tazilite theologian, 'Abd al-Jabbār, might have been responsible for forging its authorship. ${ }^{25}$

The contrasting conclusions reached by scholars studying the same stock of materials, but using dissimilar methods and approaches, illustrated to Cook 'the indefinite tolerance of the source-material for radically different historical interpretations'. ${ }^{26}$ Indeed, resolving the issue of the origins and early nature of kalām remains a seemingly elusive endeavour.Van Ess's contributions to this academic endeavour have been immense: his critical editions and commentaries of early materials serve as indispensable resources for researchers in the field. ${ }^{27}$ Through his studies our historical appreciation of the early and classical religious movements has certainly been enhanced. And, they have also provoked further debate: Cook suggested qualifying van Ess's quietist classification of the early Murji'ites. Indeed, a further review by Khalil Athamina has proposed that the movement had both radical as well as quietist elements. Interestingly, the use of projection is a theme explored in Stephen Judd's study of Ghaylān al-Dimashqī, who was legendary for his support of libertarian doctrines in these early periods; such studies paradoxically confirm that the early debates about qadar do have a historical reality. ${ }^{28}$ Other scholars have questioned van Ess's views on the political and religious implications of the doctrine of qadar. ${ }^{29}$ Of course, for the historian of kalam the question is whether the polarisation of sects and religious movements had really materialised at such early junctures in the tradition; or, is it the case that classical accounts of this period are contrived to present a somewhat rarefied view of the past. Nevertheless, while it would be an amplification to state that methodological concerns about origins are driving debates in the field of katām, they continue to impinge upon discussions germane to the early development of theology and also retain their currency in later contexts of its history.

\section{TOWARDS THE CONSOLIDATION OF ISLAMIC THEOLOGY: LATER STAGES IN THE HISTORY OF KALĀM}

An examination of the contents of typical theological summae from the formative periods of the Islamic tradition shows that the thematic compass of kalām had considerably expanded. Along with the synthesis of earlier topics such as the status of sinners, leadership of the community, it is the case that subjects such as atomism, causality, occasionalism, the inimitability of the Quran, the theodicy, intercession, prophetic miracles, and moral 
obligation were also being fleshed out in these works. The account of the theological doctrines of the sects and movements of early Islam, entitled Maqālät al-Islämiyyīn, which was composed by the eponym of Ash'arism, Abü'l-Hasan al-Ash'arī (260-324/873-935 CE) confirms that theological discourse had reached impressive levels of sophistication. Later works such as the Kitāb al-Tamhīd (the Book of Preliminaries) by the Ash'arite theologian al-Bāqillānī (d. 403/1013 CE) broached many of the theological questions in a dialectical framework with the arguments and theoretical postulates of adversaries being subjected to criticism and review. The synergy of ideas and perspectives sustained theological discourse over ensuing centuries with early works being the subject of commentaries, expositions, and even refutations. ${ }^{30}$

The contribution made by $\mathrm{Mu}^{\mathrm{c}}$ tazilite theologians to the synthesis of speculative theological thought has featured prominently in academic treatments of kaläm. Van Ess once remarked that the history of Islamic theology during the second and third centuries (eighth and nineth centuries $\mathrm{CE})$ is essentially a history of $\mathrm{Mu}^{\mathrm{c}}$ tazilism. ${ }^{31}$ The $\mathrm{Mu}^{\mathrm{c}}$ tazilites labelled themselves the upholders of 'divine unity and justice': the former related to their understanding of the concept of God's absolute transcendence, while the latter was linked to their trenchant rejection of orthodoxy's rigid doctrine of predestination. There has been a tendency among researchers to restrict the religious and political ascendancy of the $\mathrm{Mu}^{\mathrm{c}}$ tazilites to the early years of 'Abbāsid rule (133-236/750-850 CE). However, more recently, Daniel Gimaret has shown that the movement's influence was chronologically more widespread. ${ }^{32} \mathrm{He}$ stressed the point that the feature of this early period is the existence of an 'extreme diversity of people and doctrines' ${ }^{33}$ Thus, one notes that Dirār ibn 'Amr (d. 200/815 CE), the author of a work on the Aristotelian concept of accidents and substances, advocated the view that human acts were created by God, an idea fervently rejected among Mu tazilite theologians. ${ }^{34}$ An accomplished proponent of early Mu'tazilite kalàm, al-Nazzām (d. $220 / 835$ or 230/845 CE), rejected the theory of atomism elaborated by figures such as Abü'l-Hudhayl (d. 226/840-841 CE); this latter figure's concept of al-așlah (the idea that God was compelled to do his best for man) was contested by Bishr ibn al-Mu'tamir (d. 210/825 CE or 226/840 CE)..$^{35}$

One recent study of the historical roots of $\mathrm{Mu}^{\mathrm{c}}$ tazilism by Sarah Stroumsa has challenged classical as well as modern views of this movement's emergence. Traditional sources posit the rise of theology within the vector of politically inspired phenomena; and modern scholarship had tended to concur with that appraisal. ${ }^{36}$ However, Stroumsa described modern scholarship's portrayal of early Mu'tazilite history as being 'speculative reconstructions' due to the tendentious nature of the original sources. Referring to the semantic significance of the term Mu'tazila, she noted that the word originally conjured up connotations of religious asceticism and isolation, a point previously made by Ignaz Goldziher. ${ }^{37}$ Stroumsa accepted 
that Wāṣil ibn 'Ațā' (80-131/699-749 CE) was the founder of Mu'tazilite kaläm, and that he was a prolific writer who engaged in disputations with members of other faiths, a point readily recorded in the classical doxographies. ${ }^{38}$ It is in this context that another scholar, Shlomo Pines, spoke of the role of itinerant mutakallimūn (lit. those who engage in discourse) sent by Wāsil as missionaries to various parts of the regions over which Islam had gained political hegemony. ${ }^{39}$ These individuals engaged in disputations with Buddhist and Brahmin adversaries, employing 'intuitive and discursive' reasoning in their debates. ${ }^{40}$ Pines felt that their role as propagandists for the state was paramount and that they were often in competition with traditional scholars such as jurists and traditionists. ${ }^{41}$ Stroumsa reasoned that such individuals were also grappling with theological arguments presented by Jewish, Christian, Manichean and Zoroastrian adversaries. It was through this interaction and contact that kaläm flourished as the movement 'propagated its theological ideas'. ${ }^{42}$ Stroumsa concluded that the tendency to view the emergence of the Mu'tazilites in purely political terms was erroneous. ${ }^{43}$ Studies of this nature demonstrate the extent to which sensitivities towards the design of classical sources continue to impact upon debates concerning the early development of kalàm, although the sum and substance of theological thought lies in its elaboration of a rational schema for the defence of religious doctrines.

The impact of Greek philosophical abstraction upon the modes of argumentation developed by Mu'tazilite theologians is assumed to be axiomatic in many of the academic treatments of this movement. ${ }^{44}$ Van Ess made the point that key thinkers and contributors to $\mathrm{Mu}^{\mathrm{c}}$ tazilite thought such as al-Nazzām actually refined their ideas when most Greek texts were not yet available in Arabic, although van Ess sees the infiltration of thought being exercised via secondary channels such as Iranian influences. ${ }^{45}$ The tendency among researchers to look for exterior sources in the development of kaläm relates not only to issues such as the origin of the dialectical technique and early theological constructs, but also to later doctrinal discussions. Harry Wolfson's key study of kalām identifies Christian theological discussions at the heart of some of the principal debates in Islamic theological thought. ${ }^{46} \mathrm{He}$ suggested that discussions initiated by theologians on the nature of the divine attributes plainly had a Christian nexus and were prefigured by deliberations between Muslim and Christians on the doctrine of Trinity. Shlomo Pines also spoke of the influence of Christian theology, particularly the philosophy of John Philoponus (d. 500 CE), who was the author of a work refuting the Aristotelian concept of the world's eternity. ${ }^{47}$ The subject of external influences has proved to be a useful means of explaining the conceptual complexity of the ideas explored in Muslim theological thought, although like the issues of origins, authenticity and ascription, it can seemingly deflect attention from the intrinsic value of the constructs and ideas expounded upon in the sources. 
The theological thought of 'Abd al-Jabbār has formed the focus of a number of major studies. Through his literary legacy, scholars are now gaining a greater awareness of the early stages of $\mathrm{Mu}^{c}$ tazilite thought and theoretical trends in later expressions of $\mathrm{Mu}^{\mathrm{c}}$ tazilism. This is mainly due to the fact that his extant works provided researchers with a wealth of original Mu'tazilite sources. Studies on 'Abd al-Jabbār range from George Hourani's work on his approach to ethics, to J. R. Peters' influential examination of his articulation of the concept of God's created speech. More recently 'Abd al-Jabbār's theological treatment of suffering and divine justice has been reviewed in a monograph by Margaretha Heemskerk. ${ }^{48}$ The thought of

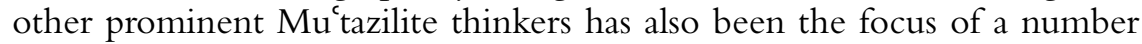
of studies. Abü'l-Husayn al-Bașrī (d. 436/1044), a pivotal figure from the classical period, has been the subject of a recent work by Wilferd Madelung and Sabine Schmidtke assessing the influence of his thought among the Karaites. ${ }^{49}$ Schmidtke, along with David Sklare, recently founded the Mu'tazilite Manuscripts Project Group. Among the profusion of recent

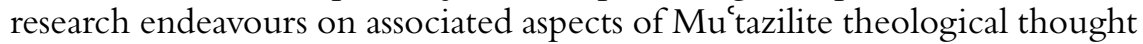
is the important review of the relationship between $\mathrm{Mu}^{\mathrm{c}}$ tazilism and Sufism by Florian Sobieroj; Sabine Schmidtke's study of the influential Shîite theologian, al-'Allāma al-Hillī (d. 726/1325) and the links between Mu'tazilism and Shîism; Dhanani Noor's monograph on atoms and space in Mu'tazilite thought; and, Peter Adamson's examination of the impact of Mu'tazilite ideas on the philosopher al-Kindī (d. 256/870)..$^{50}$

From a wider perspective the works of scholars such as Montgomery Watt, Wilferd Madelung, Richard Frank, Etan Kohlberg, Hans Daiber, Majid Fakhry, Michel Allard, Louis Gardet, Georges Anawati, Heinz Hälm and Daniel Gimaret among many others, continue to serve as important contributions to the academic study of the many strands of thought within the early and classical Islamic tradition of theology. ${ }^{51}$ Such endeavours have been supplemented by recent works, including Tilman Nagel's historical survey of Islamic theology; Patricia Crone and Franz Zimmerman's critical edition and translation of the manuscript ascribed to the Khārijite Sālim ibn Dhakwān; Andrew Newman's examination of the formative period of Twelver Shīism; Cornelia Schöck's inspired study of the conceptual intersection linking Peripatetic logic, kalām and Qur'anic exegesis; and,Asma Afsaruddin's in-depth work on the theological dynamics of leadership in the early Islamic community. ${ }^{52}$ Ismāeili theological thought has been the focus of a number of significant studies, including Farhad Daftary's historical survey of this movement and Paul Walker's monographs on the thought of a number of its influential luminaries. ${ }^{53}$ The Māturīdite school of theology together with its eponym, Abü'l-Manșūr al-Māturīdī (d. 333/944 CE), has yet to attract the sort of sustained attention that their rich theological heritage merits. ${ }^{54}$ It is worth noting that the polemical debates and discussions between Muslim and Christian theologians together with their impact upon the features of Christian theological discourse have recently been the subject of 
a number of discerning studies, including David Thomas's Early Muslim Polemic against Christianity. ${ }^{55}$ Such works underline the extensive coverage and conceptual range of the discipline of kalām.

\section{MODERN SCHOLARSHIP AND THE THEOLOGICAL IMPACT OF THE MIHNA}

While academic surveys of early theological thought can often be overwhelmed by arguments germane to authenticity and ascription, it is interesting to note that even in instances when such concerns do not arise, sharp disagreements regarding issues of interpretation can often surface. The historical episode of the mihna (inquistion) is an excellent case in point. The mihna was imposed by the 'Abbāsid caliph al-Ma'mūn (ruled 198-218/813$833 \mathrm{CE}$ ) in 198/833 CE on the advice of leading Mu'tazilite theologians, who wanted the doctrine of a created Qur'an imposed upon the class of learned scholars. The reason for the imposition of this doctrine has divided academic judgements. The orthodox champion of the mihna was the Sunnite scholar Ahmad ibn Hanbal (164-241/780-855 CE). He along with a number of scholars refused to subscribe to the doctrine of the Qur'an's createdness, arguing that there was nothing in the scriptural sources to substantiate this doctrine. On the instructions of the caliph al-Ma'mūn, Ibn Hanbal was imprisoned and eventually flogged. Despite the death of al-Ma'mūn, the mihna was continued during the successive caliphates of al-Mu'tasim (ruled 218-227/833-842 CE) and al-Wāthiq (ruled 227-232/842-847 CE), before being rescinded by al-Mutawakkil in 232/847 CE.

Madelung produced a compelling study of the doctrine of a created Qur'an. He argued that the idea was advocated in order to uphold the rationalist concept of God's transcendence. The Mu'tazilite reasoning was that if the Qur'an were construed as being the literal speech of God, it would imply that God possessed a physical organ with which he articulated words. By speaking of the Qur'an as a created document such an understanding was obviated. ${ }^{56}$ Madelung stated that the caliph was not the main instigator of this policy, but rather jurists at his court were behind its inception. On the other hand, Montgomery Watt reasoned that al-Ma'mūn's motive was essentially political. ${ }^{57} \mathrm{He}$ remarked that by supporting the view that the Qur'an was created, the text's legal power was somewhat diminished, giving greater authority to the caliph. One could argue that there is no evidence to suggest that any of the policies or legislation pursued by Ma'mūn were in need of such a doctrine; ultimately, in Watt's view, Sunnism emerged triumphant as a result of the failure of the mihna. Martin Hinds concluded that the mihna was simply about the authority of the caliphate and the role of caliphs as interpreters of the faith, suggesting that $\mathrm{Mu}^{\mathrm{c}}$ tazilite interests coincided with those of the state.$^{58}$ In Hinds' estimation the episode of the mihna was important because the caliphate lost the religious authority it had aspired to hold. Michael Cooperson turned his attention to the importance of Ahmad ibn Hanbal throughout this affair. He made the case that classical Arabic biography was later used to enhance the religious profile and status 
of this figure. Van Ess had argued that Ibn Hanbal capitulated under torture; Ibn Hanbal was released from jail while other scholars remained incarcerated until the reign of al-Mutawakkil in 233/847 $\mathrm{CE} .{ }^{59}$ Intriguingly, Cooperson has recently acknowledged that it is also plausible that Ahmad was released without capitulating. Nimrod Hurvitz described the mihna as an act of self-defence on the part of the rational theologians (mutakallimūn). ${ }^{60} \mathrm{He}$ rejected Sunni accounts of this affair, arguing they were manipulated to promote the standing of Ahmad ibn Hanbal. Hurvitz presented the view that the mihna was about the mutakallimūn responding to years of intimidation directed at them by the traditionists (ahl-al-hadith) ${ }^{61}$ Patricia Crone has expressed the view that the imposition of this doctrine should not be construed as an attempt to impose Mu'tazilite theology. ${ }^{62}$ Some of these earlier treatments of the milna have been reviewed in John Nawas's study of this episode. ${ }^{63}$

The striking feature of academic studies of the mihna is that they have not only stimulated debates about the historical consolidation of Sunnì orthodoxy within the early Islamic tradition, they have also brought into relief the question of political and religious authority within the 'Abbāsid caliphate. Among academics the event of the mihna has served as an analogue for establishing trends towards homogeneity and standardisation within the Islamic tradition. One scholar has even described it as a landmark in the triumph of traditionalism over rationalism. ${ }^{64}$ Nonetheless, it is also true that the failure of the policy of the mihna by no means presaged the waning of Mu'tazilite thought. It is becoming evident to researchers that Mu'tazilism provoked a far greater sense of purpose in orthodoxy's formulation of theological constructs to counter its philosophy; yet, ironically, this was achieved by espousing the rational methodology devised by orthodoxy's opponents. Whatever the nature of the disagreements about the design of the mihna, it has to be viewed as an important milestone in the history of kaläm. The sharp differences in academic opinion on the subject would seem to substantiate Michael Cook's comments, which were cited earlier, regarding 'the indefinite tolerance of the source-material for radically different historical interpretations'. ${ }^{65}$ They are likewise common in related studies of the Muslim experiment with scholastic theology: namely, the advent of the Ash'arite theologians and modern scholarship's appreciation of their role in its refinement.

\section{ASH'ARISM AND ORTHODOX KALA $M$}

The brand of scholastic theology cultivated by the Ash'arite theologians represents an important chapter in the flourishing of kaläm. The school's eponym, Abü'l-Hasan al-Ash' ${ }^{\text {'arì }}$, had originally been famed for his association with the Mu'tazilites. He had been a student of one of their leading luminaries, Abū 'Alī al-Jubbāî̀ (d. 303/915 CE). Yet, at some point in his life, al-Ash' ${ }^{c}$ ari renounced Mu'tazilism, dissipating considerable intellectual energies in refuting the theological theses of this school. ${ }^{66}$ One prominent 
academic who was particularly interested in attitudes towards rational theology within orthodox Islam, George Makdisi, passionately argued that the seemingly close association between orthodoxy and Ash'arism was unduly accentuated in the history of Islamic theology. Makdisi emphasised that the brand of scholastic kalām championed by Ash'arism was never fully accepted within classical Sunni orthodoxy. ${ }^{67} \mathrm{He}$ claimed that opposition to Ash'arism's rational methodology was vented among individuals of a stern religiosity who questioned the efficacy of the science of kalam, viewing it as being an abject exercise in casuistry. Classical Sunnī schools of jurisprudence including the Shāfíites, the Mālikites and the Hanafites were nominally affiliated to theological schools of thought. A number of prominent Shāfí ite and Mālikite jurists were linked with Ash'arism; while Hanafites were predominantly Māturīdite.

The Hanbalites remained staunch traditionists who generally opposed the rational methods associated with the discipline of kalam ${ }^{68}$ They and indeed the ahl al-hadith promoted the championing of more popular forms of orthodoxy. These were deemed to be rid of the sophistic tendencies of the rational theologians; many of them encouraged the formulation of creedal statements as a vehicle for the expression of dogma. ${ }^{69}$ Makdisi asserted that al-Ash'ari was no advocate of the variety of theology that later prevailed within the school, alleging that his students and their disciples were the true authors of this brand of scholastic thought. Hanbalite and indeed traditionist scholars considered Ash' ${ }^{c}$ arism to be a form of $\mathrm{Mu}^{\mathrm{c}}$ tazilism masquerading as orthodoxy. Makdisi's mentor was the scholar Henri Laoust, who was the author of several discerning studies of classical Hanbalite thought.

Makdisi's thesis was criticised by a respected academic authority on Ash'arism and classical Islamic theology, Richard Frank. ${ }^{70} \mathrm{He}$ contended that the extant works authored by al-Ash'arī display theological leanings that were generally commensurate with the doctrinal positions taken by later theologians of the school. Makdisi had alleged that several of the works ascribed to al-Ash'arī were products of the preconversion period and reflected a predisposition to $\mathrm{Mu}^{\mathrm{c}}$ tazilite inspired precepts; the issue seemingly turned on the question of ascription. Frank retorted that there existed texts which were composed by Ash 'arī after his 'conversion' reflecting the same rational outlook. Certainly, the works of early luminaries of the Ash'arite school such as the Mujarrad Maqālät al-shaykh Abìl-Hasan al-Ash'iañ (the Essential Theological Doctrines of $A b \bar{u}$ l-Hasan al-Ash'ari ), composed by Ibn Fūrak (348406/941-1015 CE), were predicated on their epitomising the irrefutable theological teachings of al-Ash ${ }^{c}{ }^{-1}{ }^{71}$ The fascinating aspect of the arguments about the position of Ash'arism within the citadel of Sunnism is that the perceived theological antithesis with the Hanbalites was not solely based on the latter's ambivalence towards the methodology of scholastic and dialectical theology. The Hanbalites rejected the basic doctrines and theses that this rational schema of thought engendered. Although, as Frank argued, Ash ${ }^{c}$ ari had condemned aggressive and contentious dialectic debate based on the 
assumption that human reason is the original and primary source of theological knowledge and arbiter of truth, he did allow formal kaläm to play a role in the defence of orthodoxy. ${ }^{72}$ Makdisi's arguments about Ash'arism are important because he identified links between scholastic theological literature and juridical works that expounded upon the roots of Islamic law; the Ash carite contribution to both these genres is immense. It is worth mentioning that in a related research effort, Frank provoked debate for his suggestion that the accepted commitment of Abū Hāmid al-Ghazālī (d. 555/1111) to Ash'arite theology was 'tenuous in the extreme'. ${ }^{73} \mathrm{He}$ identified doctrinal inconsistencies found in al-Ghazālī's works such as his position on causality, occasionalism, and the metaphysics of resurrection, claiming that obfuscation and vagueness marked al-Ghazālī's relationship

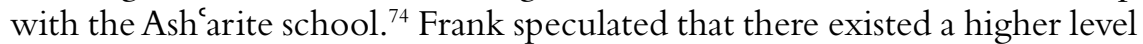
of theological understanding that defined Ghazālī's position. ${ }^{75}$ Referring to arguments outlined by Frank, Michael Marmura and Toby Mayer both produced studies that demonstrated that al-Ghazālī's commitment to Ash'arism was unquestionable, refuting Frank's interpretation of the sources. ${ }^{76}$ Conflicting conclusions of this nature confirm the conceptual complexity and sophistication of the original sources. They also reveal the wide range of approaches, methodologies and interests applied in their interpretation, confirming the extent to which disagreements relating to ascription, projection and interpretation have combined to affect studies of this school's importance. However, debates of this nature are important for gauging tensions between traditionalist and rationalist approaches to the synthesis of dogma.

The rich legacy of kaläm spans across a wide stretch of Islamic history. Contributions to its discourse were made from a diverse range of perspectives and outlooks. Some indication of the fecundity of its thought is reflected in the observation that theological discourse of the post-sixth/twelveth centuries $\mathrm{CE}$ is finer in its conceptual sophistication and theoretical dexterity than the preceding periods of its history. ${ }^{77}$ The theoretical discussions that pervade the works of scholars such as Fakhr al-Dīn al-Rāzì (d. 606/1209), Sayf al-Dīn al-Āmidī (d. 630/1233), Ibn Taymiyya (d. 728/1328), al-'Allāma al-Hillī (d. 726/1325), and al-Taftāzānī (722-791/1322-1389) could be highlighted to substantiate such remarks. Current scholarship is therefore only beginning to tap into kaläm's rich reservoir of materials. Van Ess once remarked in 1973 that Islamic studies 'are one century behind Latin medieval studies' ${ }^{78}$ In what is quite clearly a moderate estimate, he added that there exists around two million Arabic or Persian manuscripts in the world; and that there were 'some 500,000 in Istanbul alone'. He stated that only a very small portion of these has been printed. Western academic studies in fields such as Islamic theology have naturally progressed since these remarks were made. Of course, one must bear in mind that the recent academic endeavour of the Arabic and Islamic world in the field of theology and the related Islamic sciences is immense: notwithstanding the numerous critical editions of theological 
manuscripts, there exists a profusion of texts, theses and dissertations devoted to all aspects of theology. Yet, such sources are hardly given the Western academic attention they clearly warrant. Despite the many academic achievements made in the study of kalam, the quest to comprehend, encompass and appreciate the Muslim experiment with theology still remains quite a challenging endeavour.

\section{Short Biography}

Mustafa Shah is a lecturer in the Near and Middle East Department at the School of Oriental and African Studies (SOAS), London University, where he completed both his $\mathrm{BA}$ and $\mathrm{PhD}$ degrees in the field of Arabic linguistics and Islamic Studies respectively. He is also an affiliate of the Centre of Islamic Studies (SOAS), which has been host to number of major conferences on the Qur'an and the classical Islamic tradition. His principal research and teaching interests include early Arabic linguistic thought; classical Islamic theology and jurisprudence; and Qur'anic hermeneutics and exegesis. He has published articles on these subjects including: 'The Early Arabic Grammarians' Contributions to the Collection and Authentication of Qur'anic Readings: The Prelude to Ibn Mujāhid's Kitāb al-Sab'a', Journal of Qur'anic Studies (Edinburgh: Edinburgh University Press, 2004); and 'The Quest for the Origins of the Qurrä in the Classical Islamic Tradition', Journal of Qur'anic Studies (Edinburgh: Edinburgh University Press, 2005). More recently, as well as contributing to various projects such as The Islamic World (ed.), Andrew Rippin. (Routledge); and the Encyclopaedia of Arabic Language and Linguistics (ed.), Kees Versteegh, vol. IV (Leiden: E. J. Brill). $\mathrm{He}$ is also working on a number of monographs including, Religious Dogma and the Synthesis of Early Arabic Linguistic Thought, Library of Arabic Linguistics Series (London: Kegan Paul International, 2008) and Classical Interpretations of the Qur'an (London: I. B. Taurus, 2008). And he will also be editing the recently commissioned IB Taurus Biographical Dictionary of Islamic Civilization and Cultures.

\section{Notes}

* Correspondence address: Mustafa Shah, Faculty of Languages and Cultures, Near and Middle East Department, School of Oriental and African Studies, London University, Thornhaugh Street, Russell Square, London WC1H 0XG. Email: ms99@soas.ac.uk.

${ }^{1}$ Herbert Berg. (ed.), Method and Theory in the Study of Islamic Origins (Leiden: E. J. Brill, 2003), p. 261, footnote 4 .

${ }^{2}$ Herbert Berg. (ed.), Method and Theory, pp. 260-2.

3 See Ella Landau-Tasseron, 'On the Reconstruction of Lost Sources', Al-Qanțara (2004:25), pp. 45-91 and Lawrence Conrad, 'Recovering Lost Texts: Some Methodological Issues', Journal of the American Oriental Society (1993:113:2), pp. 258-63. And, Herbert Berg, (ed.), Method and Theory, pp. 284-6.

${ }^{4}$ See Gregor Schoeler. The Oral and the Written in Early Islam. Translated by Uwe Vagelpohl, edited by James E. Montgomery. Routledge Studies in Middle Eastern Literatures (London: Routledge, 2006). 
5 'Alī led an army into Syria and clashed with the latter's supporters at a place called Șiffin near Raqqa in 657 CE.

${ }^{6}$ The issue of arbitration was never satisfactorily resolved. Despite being succeeded by his son al-Hasan for a short interval, the balance of power shifted towards Muāwiya, ushering in the period of Umayyad rule $(661-750 \mathrm{CE})$. He later nominated his son Yazīd as his successor. His son's rule was marked by a set of catastrophic events: the murder of 'Alī's son al-Husayn, who challenged Yazid's political authority; the sacking of Medina; the de facto establishment of an anticaliphate led by 'Abd Allāh ibn Zubayr in the geographical region known as al-Hijāz; and the siege of the Meccan sanctuary. Events of this nature served as the backdrop for an applied theological discourse as the religious movements and sects that emerged from the imbroglio attempted to defend, define and elucidate their positions.

${ }^{7}$ Proponents of free will were referred to as ahl al-qadar or Qadarites, although they are not, as the designation literally implies, 'proponents of predestination'. Indeed, those assigned this label protested that it was unsuitable, given their position on this doctrine; the term qadar connotes power.

${ }^{8}$ Joseph Van Ess. 'The Early Development of Kaläm', in Studies on the First Century of Islamic Society (ed.), G. H. A. Juynboll (Carbondale and Edwardsville, 1982), pp. 109-23. See also pp. 110-1; Van Ess cited further evidence of the presence of the kaläm technique in Khārijite sources which he dated to the first Islamic century. Joseph Van Ess, 1970, 'The Logical Structure of Islamic Theology', in GE Grunebaum (ed.), Logic in Classical Islamic Culture, pp. 21-50, Giorgio Levi Vida Biennial Conference; 1977, Anfänge muslimischer Theologie. Zwei antiqadaritische Trakate - aus dem ersten Jahrhundert der Higra (Beiruter Texte und Studien, 14), Franz Steiner (Beirut-Wiesbaden); 1990.

${ }^{9}$ C. H. Becker, 'Christliche Polemik und islamische Dogmenbildung' Zeitschrift fur Assyriologie und verwandte, Gebiete (1912:26), p. 190.

10 The idea that these 'imāms' were infallible soon became a sacrosanct article of faith within Shî́ism. This led to debates about the legitimacy of the reign of previous caliphs such as Abū Bakr (d. 11/634 CE), 'Umar ibn al-Khatțāb (d. 23/644CE), and 'Uthmān ibn 'Affān (d. 35/655). See also Khalil Athamina, 'The Pre-Islamic Roots of the Early Muslim Caliphate: the Emergence of Abū Bakr', Der Islam (1999:76), pp. 1-32.

${ }^{11}$ His father was the caliph 'Ali's son from a second marriage, and had been nominally linked with a radical Shî ite movement in Iraq, which was known as the tawwābūn (penitents). It was established in his name to avenge the murder of 'Alī's son al-Husayn and led by an individual by the name of Mukhtār ibn 'Umar al-Thaqafi. The movement was suppressed by supporters of the anticaliph 'Abd Allāh ibn al-Zubayr. Despite having a vested interest in the political affairs of the day, Muhammad ibn al-Hanafiyya eventually retired to Medina, pledging his allegiance to the Umayyad caliph 'Abd al-Malik ibn Marwān. He was also the putative author of a second text on the subject of postponement $(i r j \vec{a})$. The text is preserved in a number of late sources and was the subject of a study by van Ess.

${ }^{12}$ Joseph Van Ess. 'The Early Development of Kaläm', p. 98. Cf. Joseph Van Ess. 'The Beginnings of Islamic Theology', The Cultural Context of Medieval Learning. Proceedings of the First International Colloquium on Philosophy, Science, and Theology in the Middle Ages. (Dordrecht: D. Reidel Publishing Company, 1973), pp. 87-111. See also his The Flowering of Muslim Theology, translated by Jane Marie Todd (Cambridge, MA: Harvard University Press, 2006).

${ }^{13}$ Joseph Van Ess. 'Early Development of Kalām' pp. 110-1. Keith Lewinstein. 'The Azāriqa in Islamic Heresiography', Bulletin of the School of Oriental and African Studies (1991:54), pp. 251-68.

${ }^{14}$ Heinz Hälm. Shi ism (Edinburgh: Edinburgh University Press, 2004), pp. 16-19.

${ }^{15}$ Michael Cook. 'The Origins of Kalām', Bulletin of the School of Oriental and African Studies (1980), pp. 32-43. Reproduced in Michael, Cook. Studies in the Origins of Early Islamic Culture and Tradition (Aldershot: Ashgate Variorum, 2004).

${ }^{16}$ Michael Cook. Early Muslim Dogma (Cambridge: Cambridge University Press, 1985).

${ }_{17}$ Cook said that the 'raw materials' of Islamic culture are 'for the most part old and familiar', adding that it 'is in the reshaping of these materials that the distinctiveness and interest of the phenomenon resides'. 'The Origins of Kalām', p. 43.

${ }_{18}$ Reference is made to its being sent to 'Umar ibn 'Abd al-'Azīz, the Umayyad caliph. See Suleiman Ali Mourad. Early Islam between Myth and History: Al-Hasan al-Bașī (d. 110H/728CE) 
and the Formation of his Legacy in Classical Islamic Scholarship (Leiden: E. J. Brill, 2006), p. 90 and pp. 121-29.

${ }^{19}$ Cf. John Wansbrough's review of Anfänge muslimischer Theologie: zwie antiqadaritische Traktate aus dem ersten Jahrhundert der Higra (Beiruter Texte und Studien, Bd. 14) Beirut: in Kommission bei Franz Steiner Verlag, Wiesbaden, 1977, in Bulletin of the School of Oriental and African Studies (1980:43.2), pp. 361-3. Joseph Van Ess, 'Umar and his Epistle Against the Qadariyya', Abr-Nahrain (1971-2:12), pp. 19-26. See also John Wansbrough, Quranic Studies: Sources and Methods of Scriptural Interpretation (Oxford: Oxford University Press, 1977), p. 91 and pp. 160-3.

${ }^{20}$ Within Sunnism a movement known as the Zāhirites was renowned for their literalist approach to the interpretation of law; yet their theological stances were not a strict reflection of this literalism.

${ }^{21}$ See Montgomery Watt. The Formative Period of Islamic Thought (Oxford: Oneworld Publications, 1998), pp. 101-5. Especially p. 104.

${ }^{22}$ Helmut Ritter. 'Studien zur Geschichte der islamischen Frommigkeit: I. Hasan al-Bașrī', Der Islam (1933:21); Julian Obermann. 'Political Theology in Early Islam: Hasan al-Bașrîs Treatise on Qadar', Journal of the American Oriental Society (1935:55), pp. 138-62; Michael Schwarz, 'The Letter of al-Hasan al-Bașī', Oriens (1967:20), pp. 15-30.

${ }^{23}$ Michael Cook. Early Muslim Dogma, pp. 117-23. Especially p. 20.

${ }^{24}$ Suleiman Ali Mourad. Early Islam between Myth and History, pp. 176-8.

${ }^{25}$ Suleiman Ali Mourad. Early Islam between Myth and History, p. 238. G. H. A. Juynboll hinted at an early date for the text, although he was not of the view that al-Hasan was its author. Mourad infers that Juynboll's views on the text were formulated on the basis of the absence of hadiths in the text; yet, this is not clear from Juynboll's remarks as he was principally dismissing Wansbrough's treatment of the text's design. Gautier Juynboll, Muslim Tradition: Studies in Chronology, Provenance and Authorship of Early hadith, Cambridge Studies in Islamic Civilisation (Cambridge: Cambridge University Press, 1983), pp. 50-1.

${ }^{26}$ Michael Cook. Early Muslim Dogma, p. 156. Van Ess placed some theoretical distance between the early Qadarites and the emergent Mu'tazilites, see 'Early Development of Kaläm', pp. 114-5.

${ }^{27}$ Joseph Van Ess. Theologie und Gesellschaft im 2. 3.jahrhundert Hidschra: eine Geschichte des religiösen Denkens im frühen Islam (Berlin: Walter de Gruyter, 1991-1995), 5 vols.

${ }^{28}$ Steven C. Judd. 'Ghaylān al-Dimashqī: The Isolation of a Heretic in Islamic Historiography', International Journal of Middle East Studies (1999:31), pp. 161-84. Judd argues that Ghaylān was a victim of incremental isolation in the historical sources; having been labelled a deviant by his Umayyad opponents, his heretical status was systematically magnified in the subsequent sources despite his close links with figures who were viewed as being paragons of orthodoxy.

${ }^{29}$ Khalil Athamina.'The Early Murji’a: Some Notes', Journal of Semitic Studies (1990:35:1), pp. 10930. Steven C. Judd, 'Ghaylān al-Dimashqī: The Isolation of a Heretic in Islamic Historiography', International Journal of Middle East Studies (1999:31), pp. 161-84. See Hasan Qasim Murad, 'Jabr and qadar in Early Islam: A Reappraisal of their Political and Religious Implications', in Islamic Studies Presented to Charles J. Adams, ed. by Wael Hallaq and Donald Little (Leiden: E. J. Brill, 1991), pp. 117 -32. cf. Patricia Crone, Medieval Islamic Political Thought (Edinburgh: Edinburgh University Press, 2005), p. 35.

${ }^{30}$ See Paul Walker. A Guide to Conclusive Proofs for the Principles of Belief [A translation of al-Juwaynīs (438-496/1028-1085), Kitāb al-Irshād ilā qawātịi al-adilla fî̀ ușūl al-ítiqāad] (Reading: Garnet Publishing, 2000). Richard McCarthy. The Theology of al-Ash'cari, The Arabic texts of al-Ash'arī's Kitäb al-Luma' and Risālat Istihluān al-Khawd fì ílm al-kaläm with briefly annotated translations, and appendices containing material pertinent to the study of al-Ash'carī (Beirut: Imprimerie Catholique, 1953).

31 Joseph Van Ess. 'Wrongdoing and Divine Omnipotence in the Theology of Abū Ishāa an-Nazzām', in T. Rudavsky (ed.), Divine Omniscience and Omnipotence in Medieval Philosophy (Dordrecht: 1985), pp. 53-67, p. 53.

${ }^{32}$ See his entry in the Gimaret, 'Mu'tazila', in the Encyclopaedia of Islam, (Leiden: E. J. Brill), 2nd edn, pp. 783-93.

33 'Mu'tazila', p. 784.

34 Montgomery Watt. Islamic Philosophy and Theology (Edinburgh: Edinburgh University Press, 1987), pp. 42-5.

${ }^{35}$ Gimaret, 'Mu'tazila', Encyclopaedia of Islam, p. 784. 
${ }^{36}$ Sarah Stroumsa, 'The Beginnings of the Mu'tazila Reconsidered', Jerusalem Studies in Arabic and Islam (1990:13), pp. 265-93. A phenomenological approach to the sources may well provide insights into attitudes and perceptions within the tradition, but one criticism against it is that it does not necessarily relate incontrovertibly neutral facts. Cf. Joseph Van Ess. 'Political Ideas in Early Islamic Religious Thought', British Journal of Middle Eastern Studies (2001:28), pp. 151-64.

${ }^{37}$ Ignaz Goldziher. 'Arabische Synonymik der Askese', Der Islam (1917:8). The inference seems logical given that al-Hasan al-Bașrī's ascetic credentials are renowned and Wāṣil was his student.

${ }^{38}$ Sarah Stroumsa, 'The Beginnings', p. 291.

39 Shlomo Pines. 'A Note on an Early Meaning of the Term Mutakallim', Israel Oriental Studies (1971:1) pp. 224-40. pp. 236-7.

${ }^{40}$ Shlomo Pines, 'A Study of the Impact of Indian, Mainly Buddhist, Thought on Some Aspects of Kalām Doctrines', Jerusalem Studies in Arabic and Islam (1994:17), pp. 182-203. Cf. Joseph Van Ess, 'Mu'tazila', Encyclopedia of Religion (New York: Macmillan Press, 1987). pp. 220-29, especially p. 221.

${ }^{41}$ Shlomo Pines, 'A Note on an Early Meaning', p. 232. See also 'Islamic Philosophy', in The Collected Works of Shlomo Pines, vol. III. Edited by Sarah Stroumsa (Jerusalem: The Magnes Press, Hebrew University of Jerusalem, 1996), pp. 3-46, especially pp. 10-6.

${ }^{42}$ Sarah Stroumsa, 'The Beginnings', p. 292. Susan Stroumsa. Freethinkers of Medieval Islam: Ibn al-Rawandi, Abū Bakr al-Rāzī and their Impact on Islamic Thought (Leiden, Boston: E. J. Brill, 1999).

${ }^{43}$ Nyberg had argued that the movement had political objectives, providing propaganda for the 'Abbāsids. See his article in the Encyclopaedia of Islam (1st edn), 787f. Cf. Tilman Nagel. The History of Islamic Theology: from Muhammad to the Present, (translated from the German: Geschichte der islamischen Theologie by Thomas Thornton). (Princeton, NJ: Markus Wiener; Hadleigh: BRAD, 2000).

${ }^{44}$ Watt spoke of the influence of Greek philosophy as far as theologians were able to use the ideas to develop their arguments; Montgomery Watt. Islamic Philosophy and Theology (Edinburgh: Edinburgh University Press, 1987), pp. 37-45; Van Ess 'Mu'tazilia', p. 228. As Oliver Leaman remarks it is important to bear in mind the theoretical opposition between philosophy and kalām. This has its roots in the subject matter and methodological premises used by the respective disciplines: the former employed philosophical tenets to evaluate rationally general religious truths; while the latter is concerned with a rational defence of dogma and faith. Oliver Leaman. Introduction to Classical Islamic Philosophy (Cambridge: Cambridge University Press, 2002), pp. 11-2 and pp. 215-6.

${ }^{45}$ See van Ess, 'Mu'tazila', p. 228. Cf. Dimitri Gutas, Greek Thought, Arabic Culture: The GraecoArabic Translation Movement in Baghdad and Early 'Abbasid Society (2nd-4th/8th-10th Centuries) (London \& New York: Routledge, 1998).

${ }^{46}$ Harry Austryn Wolfson. The Philosophy of the Kalām (Cambridge, Mass., London: Harvard Uuniversity Press, 1976). He initially discusses Maimonides' review of kalām and its sources on pp. 43-58; and also includes the view of early Orientalist scholars on the subject: pp. 59-70; this is followed by his own views on p. 112 and p. 132. He discussed the Mu'tazilite denial of the reality of attributes on pp. $132-43$. See p. 139 and p. 234. He stated that arguments about the eternal status of the Qur'an may have originated in an internal Qur'anic substrate, but they were soon linked to discussions about attributes, p. 241. A summary is set out on pp. 720-39.

${ }^{47}$ Shlomo Pines, 'A Note on an Early Meaning', see p. 225 and pp. 229-34. Cf. 'Some Traits of Christian Theological Writing in Relation to Moslem Kaläm and to Jewish Thought', in The Collected Works of Shlomo Pines, vol. III, Edited by Sarah Stroumsa (Jerusalem: The Magnes Press, Hebrew University of Jerusalem, 1996), pp. 79-119. Indeed, even topics such as Christian influences upon the theology of the Zaydite al-Qāsim ibn Ibrāhīm (d. 246/860) have been recently returned to in Madelung's 'Al-Qāsim Ibn Ibrāhīm and Christian Theology', ARAM (1991:3.1 and 2), pp. 35-44.

${ }_{48}$ Peters, J. R., God's Created Speech: a Study in the Speculative Theology of the Mu'tazilì Qāḍ̄ al-Quḍāt Abü'l-Hasan 'Abd al-Jabbār ibn Ahmad al-Hamadānī (Leiden: E. J. Brill, 1976). Margaretha Heemskerk. Suffering in the Mu'tazilite Theology: 'Abd al-Jabbär's Teaching on Pain and Divine Justice (Leiden: E. J. Brill, 2000). See also George Hourani. Islamic Rationalism: the Ethics of 'Abd al-Jabbär (Oxford: Oxford University Press, 1971); Majid Fakhry. Ethical Theories in Islam (Leiden: E. J. Brill, 1994a); Philosophy Dogma, and the Impact of Greek Thought in Islam; 1997, A Short Introduction to Islamic 
Philosophy, Theology, and Mysticism; 1999, 'Philosophy and Theology from the Eighth Century C.E. to the Present', in JL Esposito (ed.), The Oxford History of Islam, pp. 269-303, Oxford University Press, Oxford and George Hourani. Reason and Tradition in Islamic Ethics (Cambridge: Cambridge University Press, 1985); and more recently Maha, Elkaisy-Friemuth. God and Humans in Islamic Thought: 'Abd al-Jabbār, Ibn Sīnā and Al-Ghazālī (London: Routledge, 2006). Also relevant are Sherman Jackson. 'The Alchemy of Domination? Some Ash'arite Responses to Mu'tazilite Ethics', International Journal of Middle East Studies (1999:31.2), pp. 185-201; Kevin Reinhart, Before Revelation: The Boundaries of Muslim Moral Thought (Albany: State University of New York Press, 1995); and Richard Martin and Mark Woodward (with D. S. Atmaja). Defenders of Reason in Islam: Mutazilism from Medieval School to Modern Symbol (Oxford: Oneworld, 1997).

49 Sabine Schmidtke and Wilferd Madelung. Rational Theology in Interfaith Communication: Abül-Husayn al-Bașn's's Mu'tazilī Theology among the Karaites in the Fạtimid Age (Leiden: E. J. Brill, 2006). Abü'l-Husayn al-Bașrī. Tașaffuh al-adilla. The extant parts introduced and edited by Wilferd Madelung and Sabine Schmidtke. (Wiesbaden: Harrassowitz, 2006), See also Sabine Schmidtke. A Mu'tazilite Creed of az-Zamakhshari (d. 538/1144) (Al-Minhāj fi ușūl al-dīn), Edited and Translated (Stuttgart: Steiner, 1997).

${ }^{50}$ Florian Sobieroj. 'The Mu'tazila and Sufism', in Islamic Mysticism Contested: Thirteen Centuries of Controversies and Polemics, ed. by F. De Jong \& B. Radtke (Leiden: E. J. Brill, 1999), pp. 68-92. Sabine Schmidtke. The Theology of al-' Allama al-Hilli (d. 726/1325) (Berlin: Klaus Schwarz, 1991). Dhanani Noor. The Physical Theory of Kalām: Atoms, Space, and Void in Basrian Mu'tazilī Cosmology (Leiden: E. J. Brill, 1994). Peter Adamson. 'Al-Kindī and the Mu'tazila: Divine Attributes, Creation and Freedom', Arabic Sciences and Philosophy (2003:13), pp. 45-77. There has been a tendency among modern scholarship to speak of theological affinities between Mu'tazilism and early forms of Shî ism. However, Madelung has argued that the two were poles apart not only on issues such as the imāma, but also on topics such as the divine attributes, human will and predestination. See Madelung Wilferd. 'Imamism and Mu'tazilite Theology', Le Shi'isme Imamite, (1968), pp. 1330. Watt previously noted that Ibn Bābawayhi (d. 381/991) was the author of a creedal statement and that he disapproved of kaläm. Nonetheless, he also commented that eminent figures within Shīis ism such as al-Shaykh al-Mufìd (336-413/947-1022) and al-Sharîf al-Murtadā (356-435/9671044) disapproved of the reservations about the role of kalam and reason in the synthesis of religious dogma as expressed by Ibn Bābawayhi; and this tension in approaches to kalām was likewise manifested in subsequent forms of Shî ${ }^{-}$ism.

${ }^{51}$ Heinz Hälm. Shi i ism (Edinburgh: Edinburgh University Press, 2004); Etan Kohlberg. Belief and Law in Imāmī Shīism (Aldershot: Variorum; Brookfield, 1991). Madelung Wilferd. 'Imamism and Mu'tazilite Theology', Le Shi isme Imamite (1968), pp. 13-30. Also, Watt's work exploring the Formative Period. Michel Allard. Le Problème des attributes divins dans la doctrine d'al-Ash'arì de ses premiers grands disciples (Beyrouth: Imprimerie Catholique, 1965). G. Anwati, and L. Gardet. Introduction à la theologie musulman (Paris: Vrin, 1950). Daniel Gimaret. Dieu à l'image de l'homme: les anthropomorphismes de la sunna et leur interprétion par les théologiens (Paris: Cerf, 1997). Richard Frank, 1978. Beings and Their Attributes: the Teaching of the Basrian School of the Mu'tazila in the Classical Period, Albany: State University of New York Press. Hans Daiber, 1981. 'The Creed ('Aqìda) of the Hanbalite Ibn Qudāma al-Maqdisī', Studia Arabica et Islamica, Festschrift for I⿳亠sān 'Abbās on his sixtieth birthday. Ed. Wadād al-Qādī. (Beirut: American University of Beirut), pp. 105-125; 1992, 'The Science of Kalām', Arabic Sciences and Philosophy, vol. 2 pp. 7-37; 2005, Philosophy, Theology and Mysticism in Medieval Islam:Texts and Studies on the Development and History of the Kalām, vol. I, D Gutas (ed.), Ashgate,Variorum, Aldershot.

52 Patricia Crone and Fritz Zimmermann. The Epistle of Sälim ibn Dhakwān (Oxford: Oxford University Press, 2001). Andrew J. Newman, The Formative Period of Twelver Sh ${ }^{c}$ ism: Hadith as a Discourse between Qum and Baghdad (Richmond, Surrey: Curzon, 2000). Schöck, Cornelia. Koranexegese, Grammatik und Logik. Zum Verhältnis von arabischer und aristotelischer Urteils-, Konsequenz- und Schlußlehre (Leiden: E. J. Brill, 2005). Asma Afsaruddin. Excellence and Precedence: Medieval Islamic Discourse on Legitimate Leadership (Leiden: Brill, 2002).

53 Wilferd Madelung and Paul Walker. An Ismaili Heresiography, the Bāb al-shayțān from Abū Tammām's Kitāb al-Shajara (Leiden: E. J. Brill, 1998); and Hamīd al-Dìn al-Kirmānī: Isma î̀ T̀ Thought in the Age of al-Hākim (London: I. B. Taurus, 1999). Daftary, F, 1998, A Short History of the Ismailis, Edinburgh University, Edinburgh. 
${ }^{54}$ Wilferd Madelung. ‘The Spread of Māturidīsm and the Turks', in Actas IV congresso de estudos arabes e islamicos 1968, pp. 109-168, 1971. Republished in Wilferd Madelung. Religious Schools and Sects in Medieval Islam (Aldershot: Variorum, 1985). Ulrich Rudolph. al-Māturì̀t̄ und die sunnitische Theologie in Samarkand (Leiden: Brill, 1997). Wilferd Madelung, Abül-Mu'īn al-Nasafì and Ash'arī Theology', Studies in Honour of Clifford Edmund Bosworth. Volume II. The Sultan's Turret: Studies in Persian and Turkish culture. Ed. Carole Hillenbrand (Leiden: E. J. Brill, 2000), pp. 318-330. Cf. Mustafa Ceric. Roots of Synthetic Theology in Islam: A Study of the Theology of Abu Manșür al-Māturìdī (d. 333/944) (Kuala Lumpur: International Institute of Islamic Thought and Civilization, 1995). Nasafî, Maymūn ibn Muḥammad, Abū'l-Mu'īn. Tabșirat al-Adilla fi ușūl al-dīn (ed.). Claude Salama, 2 vols. (Damascus: al-Ma'had al-'Ilmī al-Faransī lìl-Dirāsāt al-'Arabiyya, 1993).

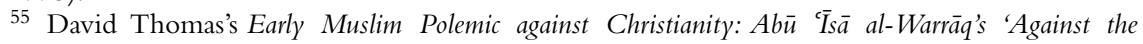
Incarnation' (Cambridge: Cambridge University Press, 2002). See also David Thomas (ed.), Christians at the Heart of Islamic Rule (Leiden: E. J. Brill, 2003).

${ }^{56}$ Wilferd Madelung. 'The Origins of the Controversy Concerning the Creation of the Qur'àn' in Félix M. Pareja Casañas (ed.), Orientalia Hispanica: sive studia FM, Pareja octogenaria dicata (Leiden: E. J. Brill, 1974), pp. 504-25. Madelung highlighted the remarks of the Hanbalite scholar Ibn Taymiyya (d. 729/1328) who said that when the pious ancestors such as Ahmad ibn Hanbal rejected the thesis of a created Quran, they had never intended to state that it was eternal (qadīm), but Sunnī theologians later spoke of this quality, endorsing it as a distinction of orthodoxy.

${ }^{57}$ Montgomery Watt. Islamic Philosophy and Theology, p. 35.

${ }^{58}$ The article is reproduced in Martin Hinds. Studies in Early Islamic History, ed. by Jere Bacharach, Lawrence I. Conrad and Patricia Crone (Princeton, NJ: Princeton University Press, 1996). Pp. 232-45. Cf. Patricia Crone and Martin Hinds. God's Caliph: Religious Authority in the First Centuries of Islam (Cambridge: Cambridge University Press, 1987). Hinds and Crone were to argue that a similar position is taken by the Umayyads in their attempt to accentuate the religious motif of khalifa in their role as caliphs.

${ }^{59}$ Michael Cooperson. Classical Arabic Biography: The Heirs of the Prophet in the Age of al-Ma'mūn (Cambridge: Cambridge University Press, 2000), p. 339, and the whole section pp.340-401. 'Two Abbasid Trials: Aḥmad ibn Hanbal and Hunayn ibn Isḥāq', Al-Qanțara (2001:22.2), pp. 375-93. Cf. Van Ess, Theologie und Gesellschaft, vol. 3, pp. 456-60 and p. 465. Van Ess produced an important study of the role of the Sunnī theologian Ibn Kullāb in the affair of the milnna.

${ }^{60}$ Nimrod Hurvitz. The Formation of Hanbalism: Piety into Power (Richmond: Curzon Press, 2002). 'Mihna as Self-defense', Studia Islamica (2001:92), pp. 93-111. See also Dominique Sourdel. 'La politique religieuse du calife 'abbaside al-Ma'mūn', Revue des etudes islamiques (1962:30), pp. 27 48.

${ }^{61}$ Nimrod Hurvitz, 'Mihna as Self-defense', p. 109. It is interesting to note that the conclusions of both Hurvitz and Stroumsa, outlined above, are largely driven by reservations concerning the Sunnī accounts of such affairs.

${ }^{62}$ Patricia Crone, Medieval Islamic Political Thought (Edinburgh: Edinburgh University Press, 2005), p. 131.

${ }^{63}$ John Nawas. 'A Re-examination of Three Current Explanations for Al-Ma’mūn's Introduction of the Mihna', International Journal of Middle East Studies (1994:26.4) pp. 615-29.

${ }^{64}$ George Makdisi. 'The Juridical Theology of Shāfíî: Origins and Significance of Ușūl al-fiqh', Studia Islamica (1984:59), p. 19. Cf. Mustafa Shah. 'The Early Arabic Grammarians' Contributions to the Collection and Authentication of Qur'anic Readings: the Prelude to Ibn Mujāhid's Kitāb al-Sab'a, Journal of Qur'anic Studies (2004:6:1), pp. 72-102.

${ }^{65}$ Michael Cook, Early Muslim Dogma, p. 156. Although, the remarks of Cook were set within the context of unravelling the history of the early Islamic tradition.

${ }^{66}$ For accounts of his 'conversion' and the famous narrative of the three brothers see Rosalind Gwynne. 'Al-Jubbāì 1 al-Ash'arī and the Three Brothers: the Uses of Fiction' Muslim World (1985:75) pp. 132-61. Cf. Montgomery Watt. Islamic Philosophy and Theology (Edinburgh: Edinburgh University Press, 1987), pp. 64-8.

${ }^{67}$ George Makdisi, 'Ash' arī and the Ash'arites in Islamic Religious History', Studia Islamica (1962:17), pp. 37-80, and (1963:18), pp. 19-39. 
${ }^{68}$ Among Hanbalite scholars there were individuals such as Ibn al-Jawzī $(511-597 / 1116-1200)$ and Abū Yálā (d. 458/1066) who both approved of rational theology. Ibn al-Jawzī was the author of a number of critiques of anthropomorphism, suggesting that fascinating variations in the modes of thought within Hanbalite theological thought existed. Merlin Swartz, A Medieval Critique of Anthropomorphism: İbn al-Jawzī's Kitāb Akhbār al-șifät: a critical edition of the Arabic text with translation, introduction and notes, English \& Arabic. (Leiden: E. J. Brill, 2002). Mustafa Shah, 'The Philological Endeavours of the Early Arabic Linguists: Theological Implications of the tawqîf-istiliāh Antithesis and the majāz Controversy'. (Part II Journal of Quranic Studies, (Edinburgh: Edinburgh University Press). School of Oriental and African Studies, Volume II, Issue I, 2000), pp. 44-66.

${ }^{69}$ Laoust, H. La Profession de foi d'Ibn Batța (Damascus, 1958). See Watt's Islamic Philosophy and Theology, pp. 98-110.

${ }^{70}$ Richard Frank. 'Elements in the Development of the Teaching of al-Ash'arī', Le Museon: Revue D’Etudes Orientales (1991:104), pp. 141-90.

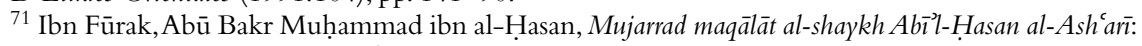
(exposé de la doctrine d'al-Ash'arī) édité par Gimaret, D., (Beyrouth: Dar el-Machreq, 1987).

${ }^{72}$ Richard Frank. 'Elements in the Development', pp. 141-85.

${ }^{73}$ Richard Frank. Al-Ghazāi and the Ash'arite School, p. x. Frank explains that Gardet and Anawati were of the view that he retains the central theses of the school but that he also forwarded certain emendations. See p. 3 and Herbert Davidson's AlFarabi, Avicenna, and Averroes on Intellect (Oxford: Oxford University Press, 1992). Frank states that the latter study confirms many of the conclusions he reached regarding Ghazālī's conception of intellectual beings: it was based on an Avicennan analogue.

${ }^{74}$ Richard Frank. Al-Ghazātī and the Ash'arite School (London: Duke University Press, 1994). Michael Marmura. 'Ghazāī and Asharism Revisited', Arabic Sciences and Philosophy (2002:12), pp. $91-110$. Ghazālì's views on causality have been the subject of numerous papers. See also Ormsby, E. L., Theodicy in Islamic Thought: the Dispute over al-Ghazäli's Best of all Possible Worlds (Princeton, NJ: Princeton University Press, 1984).

${ }^{75}$ Frank, Richard. Al-Ghazāì and the Ash'crite School (London: Duke University Press, 1994), pp. 89-90. For a review of Frank's book see Tobias Mayer's review article in Journal of Qur'anic Studies (1999:1), pp. 170-81. He argues that the higher theology that Frank infers from Ghazâlī's synthesis of theology is essentially a form of higher Ash'arism.

${ }^{76}$ Michael Marmura. 'Ghazāin and Ash'arism Revisited', Arabic Sciences and Philosophy (2002:12), pp. 91-110. cf. Richard Frank. Al-Ghazātī and the Ash'carite School (London: Duke University Press, 1994), pp. 98-9.

${ }^{77}$ Especially if ones take into account the arching of theological and philosophical trajectories of thought that becomes pronounced in these periods. See Ayman Shihadeh. 'From al-Ghazāin to al-Rāzĩ: 6th/12th Century Developments in Muslim Philosophical Theology', Arabic Sciences and Philosophy (2005:15:1), pp. 141-79. Also see his Telelogical Ethics of Fakhr al-Dīn al-Rāzì (Leiden: E. J. Brill, 2006).

${ }^{78}$ Van Ess, Joseph. 'The Beginnings of Islamic Theology', pp. 110-1.

\section{Works Cited}

Abrahamov, B, 1996, Anthropomorphism and Interpretation of the Qur'ān in the Theology of al-Qāsim ibn Ibrāhım, Kitāb al-Mustarshid edited with translation, introduction and notes, E. J. Brill, Leiden, the Netherlands.

Adamson, P, 2003, 'Al-Kindī and the Mu'tazila: Divine Attributes, Creation and Freedom', Arabic Sciences and Philosophy, vol. 13, pp. 45-77.

Afsaruddin, A, 2002, Excellence and Precedence: Medieval Islamic Discourse on Legitimate Leadership, Brill, Leiden, the Netherlands.

Allard, M, 1965, Le Problème des attributes divins dans la doctrine d'al-Ash'arī de ses premiers grands disciples, Imprimerie Catholique, Beyrouth, Lebanon.

Anwati, G, \& Gardet, L, 1950, Introduction à la theologie musulman, Vrin, Paris, France.

Athamina, K, 1990, 'The Early Murji’a: Some Notes', Journal of Semitic Studies, vol. 35, no. 1, pp. 109-30. 
1999, 'The Pre-Islamic Roots of the Early Muslim Caliphate: The Emergence of Abū Bakr', Der Islam, vol. 76, pp. 1-32.

Berg, H, (ed.), 2003, Method and Theory in the Study of Islamic Origins, E. J. Brill, Leiden, the Netherlands.

Ceric, M, 1995, Roots of Synthetic Theology in Islam: A Study of the Theology of Abū Manșūr al-Māturìd̄̄ (d. 333/944), International Institute of Islamic Thought and Civilization, Kuala Lumpur, Malaysia.

Cook, M, 1985, Early Muslim Dogma, Cambridge University Press, Cambridge, UK.

_ 2004, 'The Origins of Kaläm', Bulletin of the School of Oriental and African Studies (1980), pp. 32-43. Reproduced in Michael Cook, Studies in the Origins of Early Islamic Culture and Tradition, Ashgate Variorum, Aldershot, UK.

Cooperson, M, 2000, Classical Arabic Biography: The Heirs of the Prophet in the Age of al-Ma'mūn, Cambridge University Press, Cambridge, UK.

—_, 2001, 'Two Abbasid Trials: Aḥmad ibn Hanbal and Hunayn ibn Ishāā', Al-Qanțara, vol. 22, no. 2, pp. 375-93.

Crone, P, 2005, Medieval Islamic Political Thought, Edinburgh University Press, Edinburgh.

Crone, P, \& Zimmermann, F, 2001, The Epistle of Sālim ibn Dhakwān, Oxford University Press, Oxford.

Daftary, F, 1998, A Short History of the Ismailis, Edinburgh University Press, Edinburgh.

Daiber, H, 1981, 'The Creed ('Aqìda) of the Hanbalite Ibn Qudāma al-Maqdisì', Studia Arabica et Islamica, Festschrift for Ihsān 'Abbās on his sixtieth birthday. Ed.Wadād al-Qādī pp. 105-125. American Univerity of Beirut, Beirut.

Davidson, H, 1992, AlFarabi, Avicenna, and Averroes on Intellect, Oxford University Press, Oxford, UK.

De Jong, F, \& Radtke, B, (eds.). 1999, Islamic Mysticism Contested: Thirteen Centuries of Controversies and Polemics, E. J. Brill, Leiden, The Netherlands.

Dhanani, N, 1994, The Physical Theory of Kalām: Atoms, Space, and Void in Basrian Mutazilī Cosmology, E. J. Brill, Leiden, The Netherlands.

Elkaisy-Friemuth, M, 2006, God and Humans in Islamic Thought, 'Abd al-Jabbār, Ibn Sīnā and Al-Ghazālī, Routledge, London.

Fakhry, M, 1994a, Ethical Theories in Islam, E. J. Brill, Leiden, the Netherlands.

— 1994b, Philosophy, Dogma, and the Impact of Greek Thought in Islam, Variorum, Aldershot, UK.

—, 1997, A Short Introduction to Islamic Philosophy, Theology, and Mysticism, OneWorld, Oxford, UK.

- 1999, 'Philosophy and Theology from the Eighth Century C.E. to the Present', in JL Esposito (eds.), The Oxford History of Islam, pp. 269-303, Oxford University Press, Oxford.

Frank, R, 1968, 'The Kaläm: An Art of Contradiction-Making or Theological Science? Some Remarks on the Question', Journal of the American Oriental Society, vol. 88, pp. 295-309.

_ 1978, Beings and Their Attributes: the Teaching of the Basrian School of the Mutazila in the Classical Period, State University of New York Press, Albany.

— , 1991, 'Elements in the Development of the Teaching of al-Ash'arī', Le Muséon: Revue

D’Études Orientales, vol. 104, pp. 141-90.

_ 1992, 'The Science of Kalām', Arabic Sciences and Philosophy, vol. 2, pp. 7-37.

— 1994, Al-Ghazāti and the Ash'arite School, Duke University Press, London.

—, 2005, Philosophy, Theology and Mysticism in Medieval Islam: Texts and Studies on the Development and History of Kalām, vol. 1, D Gutas (ed.), Ashgate, Variorum, Aldershot.

Gimaret, D, 1997, Dieu à l'image de l'homme: les anthropomorphismes de la sunna et leur interprétion par les théologiens, Cerf, Paris, France.

Gutas, D, 1998, Greek Thought, Arabic Culture: The Graeco-Arabic Translation Movement in Baghdad and Early 'Abbasid Society (2nd-4th/8th-10th Centuries), Routledge, London.

Gwynne, R, 1985, 'Al-Jubbǟ̄ì al-Ash'arī and the Three Brothers: the Uses of Fiction', Muslim World, vol. 75, pp. 132-61.

Hallaq, W, \& Little, D, 1991, Islamic Studies Presented to Charles J. Adams, E. J. Brill, Leiden.

Hälm, H, 2004, Shi'ism, Edinburgh University Press, Edinburgh, UK.

Heemskerk, M, 2000, Suffering in the Mu'tazilite Theology: 'Abd al-Jabbär's Teaching on Pain and Divine Justice, E. J. Brill, Leiden, the Netherlands. 
Hourani, G, 1985, Reason and Tradition in Islamic Ethics, Cambridge University Press, Cambridge, UK.

Hurvitz, N, 2001, 'Mihna as Self-defense', Studia Islamica, vol. 92, pp. 93-111.

- , 2002b, The Formation of Hanbalism: Piety into Power, Curzon Press, Richmond.

Jackson, S, 1999, 'The Alchemy of Domination? Some Ash'arite Responses to Mu'tazilite Ethics', International Journal of Middle East Studies, vol. 31, no. 2, pp. 185-201.

Judd, SC, 1999, 'Ghaylān al-Dimashqī: The Isolation of a Heretic in Islamic Historiography', International Journal of Middle East Studies, vol. 31, pp. 161-84.

Juynboll, G, 1983, Muslim Tradition: Studies in Chronology, Provenance and Authorship of Early Hadith, Cambridge Studies in Islamic Civilisation, Cambridge University Press, Cambridge.

Kohlberg, E, 1991, Belief and Law in Imamı Shi ism, Variorum, Aldershot.

Landau-Tasseron, E, 2004, 'On the Reconstruction of Lost Sources', Al-Qanțara, vol. 25, pp. 45-91.

Leaman, O, 2002, Introduction to Classical Islamic Philosophy, Cambridge University Press, Cambridge, UK.

Lewinstein, K, 1991, 'The Azāriqa in Islamic Heresiography', Bulletin of the School of Oriental and African Studies, vol. 54, pp. 251-68.

Madelung, W, 1971, 'The Spread of Maturidism and the Turks', in Actas do IV Congresso de Estudos Arabes e Islamicos 1968, pp. 109-68, E. J. Brill, Leiden, the Netherlands.

- 1974, 'The Origins of the Controversy Concerning the Creation of the Qurān', in FM. Pareja Casañas (ed.), Orientalia Hispanica: sive studia FM, Pareja octogenaria dicata, pp. 504-25, E. J. Brill, Leiden, The Netherlands.

_ 1985, Religious Schools and Sects in Medieval Islam, Variorum, Aldershot.

_ 1991, 'Al-Qāsim Ibn Ibrāhīm and Christian Theology', ARAM, vol. 3, nos. 1\&2, pp. 35-44.

_ 2000, Abü'l-Mu'in al-Nasafi and Ash'arī Theology', in C Hillenbrand (ed.), Studies in Honour of Clifford Edmund Bosworth, vol. II. The Sultan's Turret: Studies in Persian and Turkish culture, pp. 318-30, E. J. Brill, Leiden, the Netherlands.

Madelung, W, \& Schmidtke, S, 2006, Abü’l-Husayn al-Bașrī. Tașaffuh al-adilla. The extant parts introduced and edited. Harrassowitz, Wiesbaden, Germany.

Madelung, W, \& Walker, P, 1998, An Ismaili Heresiography, the bāb al-shaytān from Abū Tammām's Kitāb al-Shajara, E. J. Brill, Leiden, the Netherlands.

Makdisi, G, 1962, 1963, 'Ash'arī and the Ash'arites in Islamic Religious History', (Part I and II), Studia Islamica (1962:17), pp. 37-80 and (1963:18), pp. 19-39.

_ 1984, 'The Juridical Theology of Shāfí1: Origins and Significance of Ușūl al-fiqh', Studia Islamica, vol. 59, pp. 5-47.

Marmura, M, 2002, 'Ghazātī and Ash'arism Revisited', Arabic Sciences and Philosophy, vol. 12, pp. 91-110.

Martin, R, \& Woodward, M (with DS Atmaja), 1997, Defenders of Reason in Islam: Mu'tazilism from Medieval School to Modern Symbol, Oneworld, Oxford, UK.

McCarthy, R, 1953, The Theology of al-Ash'arī, The Arabic texts of al-Ash'ar̄̄’s Kitāb al-Luma' and Risālat Istihsān al-Khawd fi cilm al-kalām, with briefly annotated translations, and appendices containing material pertinent to the study of al-Ash arī, Imprimerie Catholique, Beirut, Lebanon.

McDermott, M, 1978, The Theology of al-Shaykh al-Mufid, Dar el-Machreq, Beirut, Lebanon.

Mourad, SA, 2006, Early Islam between Myth and History: Al-Hasan al-Bașī (d. 110H/728CE) and the Formation of his Legacy in Classical Islamic Scholarship, E. J. Brill, Leiden, The Netherlands.

Nagel, T, 2000, The History of Islamic Theology: From Muhammad to the Present, translated from the German: Geschichte der islamischen Theologie by Thomas Thornton, Markus Wiener, Princeton, NJ; BRAD, Hadleigh.

Nawas, J, 1994, 'A Re-examination of Three Current Explanations for Al-Ma’mūn's Introduction of the Mihna', International Journal of Middle East Studies, vol. 26, no. 4, pp. 615-29.

Newman, AJ, 2000, The Formative Period of Twelver Shi ism: Hadith as a Discourse between Qum and Baghdad, Curzon, Richmond, Surrey, UK.

Obermann, J, 1935, 'Political Theology in Early Islam: Hasan al-Bașrīs Treatise on Qadar', Journal of the American Oriental Society, vol. 55, pp. 138-62.

Ormsby, E, 1984, Theodicy in Islamic Thought: the Dispute over al-Ghazälì's Best of all Possible Worlds, Princeton University Press, Princeton, NJ. 
Peters, JR, 1976, God's Created Speech: a Study in the Speculative Theology of the Mu'tazilī Qāḍ̄ al-Qudāt Abū'l-Hasan 'Abd al-Jabbār ibn Ahmad al-Hamadānī, E. J. Brill, Leiden, the Netherlands.

Pines, S, 1996, The Collected Works of Shlomo Pines, vol. III, edited by Sarah Stroumsa, The Magnes Press, Hebrew University of Jerusalem, Jerusalem, Israel.

— 1971 , 'A Note on an Early Meaning of the Term Mutakallim', Israel Oriental Studies, vol. 1, pp. 224-40.

- 1994, 'A Study of the Impact of Indian, Mainly Buddhist, Thought on Some Aspects of kalām Doctrines', Jerusalem Studies in Arabic and Islam, vol. 17, pp. 182-203.

Reinhart, K, 1995, Before Revelation: The Boundaries of Muslim Moral Thought, State University of New York Press, Albany, NY.

Rudavsky, T, (ed.), 1985, Divine Omniscience and Omnipotence in Medieval Philosophy, Reidel, Dordrecht, The Netherlands.

Rudolph, U, 1997, Al-Māturìd̄̄ und die sunnitische Theologie in Samarkand, E. J. Brill, Leiden, the Netherlands.

Schmidtke, S, \& Madelung, W, 2006, Rational Theology in Interfaith Communication: Abül-Husayn al-Bașrì's Mu'tazilī Theology Among the Karaites in the Fätimid Age, E. J. Brill, Leiden, the Netherlands.

Schmidtke, S, 1991, The Theology of al-'Allama al-Hillī (d. 726/1325), Klaus Schwarz, Berlin, Germany.

—_, 1997, A Mu'tazilite Creed of az-Zamakhsharī (d. 538/1144) (Al-Minhāj fi uṣūl al-dīn), Steiner, Stuttgart, Germany.

Schöck, C, 2005, Koranexegese, Grammatik und Logik, Zum Verhältnis von arabischer und aristotelischer Urteils-, Konsequenz-und Schluṣlehre. E.J. Brill, Leiden.

Schoeler, G, 2006, The Oral and the Written in Early Islam, translated by Uwe Vagelpohl (Routledge Studies in Middle Eastern Literatures), Routledge, London.

Schwarz, M, 1967, 'The Letter of al-Hasan al-Bașī', Oriens, vol. 20, pp. 15-30.

Shah, M, 2004, 'The Early Arabic Grammarians' Contributions to the Collection and Authentication of Qur'anic Readings: the Prelude to Ibn Mujāhid's Kitāb al-Sab'a, Journal of Qur'anic Studies, 6:1, pp. 72-102.

— ' 'The Philological Endeavours of the Early Arabic Linguists: Theological Implications of the tawqīf-iștilāh Antithesis and the majāz Controversy'. (Part II Journal of Qur'anic Studies, Edinburgh University Press, Edinburgh, 2:1, pp. 44-66.

Shihadeh, A, 2005, 'From al-Ghazālī to al-Rāzī: 6th/12th Century Developments in Muslim Philosophical Theology', Arabic Sciences and Philosophy, vol. 15, no. 1, pp. 141-79.

— 2006, Telelogical Ethics of Fakhr al-Din al-Rāzì, E. J. Brill, Leiden, The Netherlands.

Stroumsa, S, 1990 'The Beginnings of the Mu'tazila Reconsidered', Jerusalem Studies in Arabic and Islam, vol. 13, pp. 265-93.

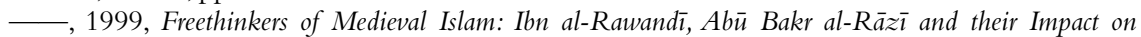
Islamic Thought, E. J. Brill, Leiden, the Netherlands.

Swartz, M, 2002, A Medieval Critique of Anthropomorphism: Ibn al-Jawzī's Kitāb Akhbār al-șifät, a critical edition of the Arabic text with translation, introduction and notes, English \& Arabic, E. J. Brill, Leiden, The Netherlands.

Thomas, D, (ed.), 2003, Christians at the Heart of Islamic Rule, E. J. Brill, Leiden, The Netherlands.

—_, 2002, Early Muslim Polemic against Christianity: Abū 'İsā al-Warrāq's 'Against the Incarnation', Cambridge University Press, Cambridge, UK.

Van Ess, J, 1970, 'The Logical Structure of Islamic Theology', in GE Grunebaum, (ed.), Logic in Classical Islamic Culture, pp. 21-50, Giorgio Levi Della Vida Biennial Conference, Otto Harrassowitz, Germany, University of California, Wiesbaden.

— 1973, 'The Beginnings of Islamic Theology', in The Cultural Context of Medieval Learning, pp. 87-111, Proceedings of the First International Colloquium on Philosophy, Science, and Theology in the Middle Ages, D. Reidel Publishing Company, Dordrecht.

— 1977, Anfänge muslimischer Theologie. Zwei antiqadaritische Traktate aus dem ersten Jahrhundert der Higra (Beiruter Texte und Studien, 14), Franz Steiner (Beirut-Wiesbaden).

— 1982 , 'Early Development of Kalàm', in GHA Juynboll (ed.), Studies on the First Century of Islamic Society, pp. 109-23, Southern Illinois University Press, Carbondale and Edwardsville, IL. 
1985, 'Wrongdoing and Divine Omnipotence in the Theology of Abū Ishāq an-Nażām', in T Rudavsky (ed.), Divine Omniscience and Omnipotence in Medieval Philosophy, pp. 53-67, Reidel, Dordrecht, The Netherlands.

-, 1987, 'Mu'tazila', Encyclopedia of Religion, Macmillan Press, New York, NY.

, 1990, 'Ibn Kullāb und de Mihna', translated by Claude Gilliot, Arabica, vol. 37, pp. 173-233. , 1991-1995, Theologie und Gesellschaft im 2. 3. jahrhundert Hidschra, 5 vols, Walter de Gruyter, Berlin, Germany.

- 2001, 'Political Ideas in Early Islamic Religious Thought', British Journal of Middle Eastern Studies, vol. 28, pp. 151-64.

— 2006, The Flowering of Muslim Theology, translated by Jane Marie Todd, Harvard University Press, Cambridge, UK.

Walker, P, 1999, Hamìd al-Dīn al-Kirmānī: Ismaîtī Thought in the Age of al-Hākim, I. B. Taurus, London.

, 2000, A Guide to Conclusive Proofs for the Principles of Belief (A Translation of al-Juwaynīs

Kitāb al-Irshād ilā qawāid al-adilla fì ușūl al-ítiqād), Garnet Publishing, Reading, UK.

Watt, M, 1987, Islamic Philosophy and Theology, Edinburgh University Press, Edinburgh, UK.

, 1998, The Formative Period of Islamic Thought, first published in 1973 by Edinburgh University

Press, Oneworld Publications, Oxford, UK.

Wolfson, HA, 1976, The Philosophy of the Kaläm, Harvard University Press. 